\title{
BESEDNOVRSTNA KATEGORIZACIJA KOT SLOVNIČNI TEMELJ POMENSKEGA OPISA V SLOVARJU
}

\section{Jerica SNOJ}

Inštitut za slovenski jezik Frana Ramovša

Snoj, J. (2018): Besednovrstna kategorizacija kot slovnični temelj pomenskega opisa v slovarju. Slovenščina 2.o, 2018 (2): 206-226.

DOI: http://dx.doi.org/10.4312/slo2.0.2018.2.206-226.

V prispevku se obravnava besednovrstna kategorizacija s stališča navajanja besednovrstnih oznak $\mathrm{v}$ slovarskem priročniku za slovenski jezik na splošni ravni, veljavni ne glede na določeni slovarski koncept. Uvodoma je prikazana svojskost besednovrstnega kategoriziranja v slovnični teoriji, čemur sledi ponazoritev vloge besednovrstnega določanja leksikalnih enot znotraj slovarskega pomenskega opisa. Ob primerih za povedkovnik, členek in izdeležniške tvorjenke je prikazan razvoj besednovrstnega kategoriziranja $\mathrm{v}$ doslejšnjih slovenskih slovarjih in na osnovi tega so podane smernice za besednovrstno označevanje leksikalnih enot $\mathrm{v}$ prihodnjih slovenskih slovarskih priročnikih.

Ključne besede: jezikovni opis, pomen, slovnica

\section{UVOD}

Pomenska analiza, na osnovi katere nastane pomenski opis leksikalne enote $\mathrm{v}$ slovarju, vključuje besednovrstno kategorizacijo kot nujni organizacijski temelj celotnega slovarskega prikaza, tako v okviru posameznega slovarskega sestavka kot na ravni zgradbe celotnega slovarskega priročnika. Besedne vrste, ki so v slovnični znanosti definirane kot abstrakcija zlasti skladenjskih značilnosti besedja, so v slovaropisju kategorizacijsko sredstvo, ki omogoča enotno obravnavo določenih razredov leksikalnih enot, s čimer se $\mathrm{v}$ celovitem pomenskem opisu zagotavlja nujna usklajenost in enotnost. Besednovrstna 
kategorizacija je $\mathrm{v}$ tej vlogi temeljnega pomena ne glede na to, katere vrste je gradivo, s katerim se pripravlja slovar; gradivo mora biti v vsakem primeru ustrezno pripravljeno, da je omogočena interpretativna pomenska analiza, v temelju vključujoča besednovrstno kategorizacijo. V postopku slovaropisne identifikacije posamezne leksikalne enote in nato $\mathrm{v}$ njenem pomenskem opisu se tako vsakokrat znova soočata slovnična definicija besedne vrste kot slovnične kategorije in celotni nabor pomenskih značilnosti te enote. Na izrazni ravni slovarskega pomenskega opisa je rezultat tega postopka razviden v obliki, kot jo določa pri vsakem slovarju slovarski koncept.

Besednovrstna kategorizacija slovenskega jezika je v zadnjem času deležna precejšnje pozornosti $\mathrm{z}$ različnih stališč. ${ }^{1}$ Prispevek se tem obravnavam pridružuje tako, da izhaja iz neposrednih slovaropisnih izkušenj, pridobljenih pri pomenskih analizah in pri sestavljanju slovarskih sestavkov v slovenskih slovarjih. ${ }^{2}$ Osredotoča se na vprašanja, kot jih zastavlja upoštevanje besednovrstne kategorizacije in praktično navajanje besednovrstnih oznak v predpostavljenem slovarskem priročniku na splošni ravni, veljavni ne glede na specifični slovarski koncept. ${ }^{3} \mathrm{~V}$ tem okviru se predpostavlja slovarski priročnik kot zaključeno leksikografsko delo, obstoječe v elektronski obliki ali v knjižni obliki, $\mathrm{v}$ obeh primerih pa na ravni zaključenega slovaropisnega izdelka $\mathrm{z}$ razvidno zasnovo in eksplikacijo pomenskega opisa, ki v svoji celovitosti omogoča uporabniku vpogled $\mathrm{v}$ pomensko razčlenjenost sodobnega slovenskega besedja.4 Zanima nas torej eksplicitno izražanje besednovrstne kategorialnosti, ki mora biti $\mathrm{v}$ kvalitetnem slovarskem priročniku za uporabnika razvidno in nedvoumno, če naj bo v podporo v slovarskem sestavku

\footnotetext{
${ }^{1}$ V ospredju so zlasti objave: Balažic Bulc 2015, Grošelj 2015, Žele 2015, Gantar 2015, Snoj 2015, Stramljič Breznik 2014.

2 Ti slovarji so: Slovar slovenskega knjižnega jezika (prva izdaja), Slovar Slovenskega pravopisa (2001) in Sinonimni slovar slovenskega jezika (2016).

3 Razmerje med obravnavo besednovrstne kategorizacije v slovnici nasproti tisti v slovarju je sicer podrobneje obravnavano v Snoj 2015.

4 Iz navedenega naj bi bilo razvidno, da se v tukajšnji obravnavi ločujeta slovarski priročnik kot v samem sebi zaključen leksikografski izdelek in leksikalna baza z drugačno, specifično funkcijo. Prim. Gantar 2015: 116.
} 
prikazani pomenski razčlenitvi.

Obravnava je uvedena s povzetkom o značaju besednovrstnega kategoriziranja v slovnični teoriji, temu sledi prikaz mesta besednovrstne kategorizacije znotraj koncepta leksikalnega pomena. V nadaljevanju je ob nekaterih primerih ponazorjeno, zakaj je v slovaropisju nujno dosledno podrejanje besednovrstne kategorizacije leksikalnemu pomenu kot celoviti jezikovnopomenski danosti.

\section{BESEDNE VRSTE V SLOVNICI}

V skladu s splošno predstavo je, da slovar prevzema že izdelane definicije besednih vrst iz slovnice in besedje za slovar razvršča in opremlja $\mathrm{z}$ besednovrstnimi oznakami glede na te definicije. V kolikšni meri ta predstava ustreza dejanskosti, je mogoče presojati tako, da se s tega vidika oceni obravnava besednih vrst $\mathrm{v}$ za slovenski jezik referenčni slovnici Jožeta Toporišiča (Toporišič 2004).

$\mathrm{V}$ slovnici je težišče obravnave besednih vrst $\mathrm{v}$ oblikovanju definicij za posamezne kategorije s poudarkom na njihovi medsebojni različnosti. Slovnica J. Toporišiča obravnava besedne vrste v okviru oblikoslovja, torej »tistega dela slovnice, ki slovarskim enotam določa vrstne, oblikovne in funkcijske značilnosti« (Toporišič 2004: 255). Besedne vrste so predstavljene »kot pojmi za množice besed z enakimi skladenjskimi vlogami in drugimi lastnostmi «, od katerih so nakazane »npr. tvorjenost, slovnične kategorije, konverzivnost ipd.«. Uvodni določitvi pojma »besedna vrsta « in navedbi devetih v slovenskem jeziku prepoznanih besednih vrst neposredno sledijo splošni opisi kategorij, s katerimi so posamezne besedne vrste razločevane: pregibnost, oblikoslovna vzorčenost, naglasna vzorčenost, morfematika; v ločeni skupini z naslovom »Inherentne kategorije sklonljivega« so prikazane kategorije spol, sklon, število, številskost in oseba. Splošni opis kategorij se zaključuje z razdelkom »Drugo«, ki napoveduje, da so pri razločevanju besednih vrst udeležene še druge kategorije, prikazane pri obravnavi posameznih besednih vrst (Toporišič 2004: 255-273). S tem pristopom je eksplicitno izraženo, v čem temelji 
razmejevanje, ločevanje besednih vrst in pripravljena je pot v posamezni opis vsake od njih. Znotraj teh opisov (samostalniška beseda, pridevniška beseda, glagol itd.) so nato podrobneje obravnavane za vsako od besednih vrst relevantne razločevalne kategorije tako, da so obsežno in izčrpno prikazane njihove oblikoslovne in skladenjske značilnosti.

Slovenska slovnica slovarniku omogoča, da si izoblikuje razmeroma jasno predstavo o besednih vrstah kar zadeva oblikoslovne in skladenjske značilnosti posameznih kategorij. 5 Povezanost besednovrstne kategorizacije z leksikalnim pomenom pa slovnica tega tipa pričakovano zgolj okvirno nakazuje, pri posameznih besednih vrstah v različni meri. Tako je npr. pri samostalniški besedi in pridevniški besedi prikaz besednovrstnih razločevalnih lastnosti razdeljen v obsežno predstavitev »skladenjskih lastnosti « in v kratek povzetek o »pomenskih lastnostih « (Toporišič 2004: 274, 318), toliko da je nakazano, kako je dana besedna vrsta kot kategorija določena z obojno razločevalnostjo.

Pomenskim lastnostim v ožjem smislu je v Slovenski slovnici J. Toporišiča še največja pozornost namenjena $\mathrm{v}$ tem, da se $\mathrm{z}$ njimi utemeljujejo nekatere obsežne podrazvrstitve znotraj dane besedne vrste. Tako je npr. besedna vrsta členek prikazana celo z dvema podrazvrstitvama, ki temeljita na pomenskih lastnostih in sta še dalje členjeni $\mathrm{v}$ mnoge podrazvrstitve. Tako podrobna pomenska členitev naj bi bila prikladna za slovarnika, saj se s svojo obsežno razčlenjenostjo kaže kot popolni povzetek mogočih leksikalnih pomenov pri tej besedni vrsti. Če pa se ta obsežna pomenska razčlenitev primerja s samo kategorialno definicijo členka kot besedne vrste, postane jasno, da ima obsežna pomenska razčlenitev vlogo nujnega dopolnila ali celo nadomestka za skopo kategorialno definicijo, ki odraža dejstvo, da je členek kategorialno težje določljiv in da se nekateri členki »po vlogi približujejo veznikom, drugi

\footnotetext{
5 Izraz »slovenska slovnica « se v tem kontekstu nanaša pretežno na slovnično védenje o besednih vrstah, kot ga vsebuje Slovenska slovnica J. Toporišiča in kot je razviden v Slovenskem pravopisu 2001; kljub pomanjkljivostim in starosti je to najsodobnejši celoviti opis besednovrstnosti slovenskega jezika in zato trenutno edini, ki je uporaben v praktičnem slovaropisju.
} 
prislovom «, poleg tega je okrog ena četrtina členkov enakozvočna z vezniki in prislovi (Toporišič 2004: 445).

Ne glede na obstoječe definicije besednih vrst v slovnici ostaja raziskovanje povezave med besednovrstno kategorizacijo in leksikalnim pomenom dane leksikalne enote naloga slovaropisca.

\section{SPLOŠNO O BESEDNOVRSTNI KATEGORIZACIJI V SLOVARSKEM POMENSKEM OPISU}

Besednovrstna kategorizacija kot leksikalnopomenska danost je v jeziku zmeraj realno prisotna v pomenskorazločevalni vlogi; naloga slovaropisca je, da jo pri posamezni leksikalni enoti ustrezno identificira. Besednovrstne oznake kot slovaropisna dogovorna oblika navajanja besednovrstne kategorizacije so $\mathrm{v}$ slovarskem priročniku eden od običajnih, pričakovanih podatkov, s katerim je v slovarju identificirana vsaka iztočnica. Na najbolj splošni ravni besednovrstna oznaka izraža umestitev jezikovnega izraza $\mathrm{v}$ poimenovalni sistem danega jezika, saj v gospodarni obliki prikazuje številne lastnosti leksikalne enote: skladenjsko vlogo v stavčni povedi, pregibanjske značilnosti, tipski denotativni pomen. Uporabnik slovarja se pri povprečno zahtevni uporabi slovarja vsebine in organizacijske vloge teh oznak v celoti navadno niti ne zaveda. Toliko bolj pa se mora te vloge zavedati slovarnik, ki mora označevanje izpeljati tako, da so leksikalne enote določene besednovrstne kategorije prikazane enako, v skladu s pomensko vrednostjo dane kategorije.

Glede na to, da se besedne vrste pojmujejo kot slovnična danost, bi se lahko pričakovalo, da so dokončno definirane v slovnici in da je s tem že rešeno tudi vprašanje besednovrstnega določanja $\mathrm{v}$ slovaropisju. Pri neposrednem oblikovanju slovarskega sestavka v skladu z danim slovarskim konceptom in upoštevaje za slovar določeno besedilno gradivo se, nasprotno, potrjuje tipična razlika, tudi sicer obstoječa med pogledom slovnice na jezikovno resničnost in potrebami slovaropisja pri slovarskem prikazu te resničnosti. Slovnica je v zvezi $\mathrm{z}$ besednimi vrstami zavezana ugotavljanju in definiranju besednih vrst kot 
kategorij znotraj slovničnega opisa danega jezika; v slovarskem priročniku pa naj bi bilo za vsako leksikalno enoto ali sestavino večbesedne leksikalne enote navedeno, $v$ katero besednovrstno kategorijo se uvršča. $V$ idealnem primeru bi slovnica imela predvidene in definirane besednovrstne kategorije, $\mathrm{s}$ katerimi bi bilo mogoče nedvoumno kategorizirati prav vse leksikalne enote in njihove sestavine. V slovaropisnih priročnikih se ta postopek prikazuje kot neproblematično opisovanje slovničnih lastnosti leksikalnih enot in njihovih sestavin; z navedbo besednovrstne oznake naj bi bila podana temeljna slovnica v zvezi z določeno leksikalno enoto skoraj v celoti. ${ }^{6}$ Besednovrstne oznake so neproblematične celo s stališča izbire, kaj v slovarju navajati iz leksikalne baze, saj so samoumevne (Attkins 2008: 219, 400). Dejansko pa prav v slovaropisju postane jasno, da jezikovna resničnost s svojo kompleksnostjo idealnosti slovničnega opisa $\mathrm{v}$ nekaterih primerih nasprotuje. $\mathrm{V}$ realizaciji slovarskega priročnika ima poleg tega besedo še slovarski koncept, ki postavlja svojske zahteve glede izraženosti besednovrstnega kategorizacijskega sistema.

Besednovrstno označevanje v slovarju dejansko vključuje soočenje enkratnih pomenskih lastnosti dane leksikalne enote s kategorizacijo besednih vrst, kot je dostopna v slovničnem opisu danega jezika. Slovnični opis slovenskega jezika sicer vključuje definicije posameznih besednih vrst, vendar to še ne zadošča za oblikovanje praktično uporabnega temelja, na katerem bi se gradila besednovrstna kategorizacija v slovarju. Uvrstitev leksikalne enote v določeno besednovrstno kategorijo ima ustrezno vsebino v pomenskem opisu leksikalne enote samo, če je besednovrstna kategorizacija sama po sebi (kot slovnična danost) pojmovana kot sestavina leksikalnega pomena.

$\mathrm{V}$ tem pogledu se v praktičnem slovaropisju kot primerno uporaben potrjuje strukturalni model leksikalnega pomena, vključujoč denotativni pomen in

\footnotetext{
${ }^{6}$ Besednovrstna kategorizacija je v slovaropisnem priročniku lahko obravnavana na docela tehnični ravni, v okviru navodil za oblikovanje slovarskih razlag. Eno takih navodil je, da mora biti razlagalna beseda besednovrstno enakovredna razlagani besedi. Za posamezne besedne vrste se lahko predvidijo čisto določene tipske razlage ipd. Prim. Landau 2008: 138-144.
} 
kategorialni pomen kot obvezna neločljiva dela leksikalnega pomena, vključno z izhodiščem, da ima vsaka leksikalna enota določljivi leksikalni pomen (Vidovič Muha 2013: 17-113). Kategorialni pomen, obstoječ v kategorialnih pomenskih lastnostih (npr. sklanjatev, števnost pri samostalniku, glagolski vid, vezljivost pri glagolu, stopnjevanje, določnost pri pridevniku itd.), je nosilec besednovrstne kategorizacije. Kategorialne pomenske sestavine, uresničevalke kategorialnih pomenskih lastnosti v pomenskih realizacijah leksikalnih enot (npr. števno+, števno-, moški/ženski/srednji spol, dovršnost/nedovršnost itd.), so besedilna konkretizacija besednovrstne kategorialnosti kot sistemske danosti. Ob tako modeliranem leksikalnem pomenu je omogočen enotni pogled na vlogo besednovrstne kategorizacije pri raznovrstnih leksikalnih enotah, kar je v zvezi s pomenskim opisom v slovarju bistvenega pomena. ${ }^{7}$

\section{RAZVOJNOST BESEDNOVRSTNEGA KATEGORIZIRANJA V SLOVENSKIH SLOVARJIH}

Tako iz slovarskih prikazov kot iz načelne obravnave besednovrstne problematike je razvidno, da nekatera vprašanja povzročajo dvome in nesoglasja glede besednovrstne kategorizacije in sploh glede slovarskega prikaza vse od SSKJ dalje. ${ }^{8}$ Med v tem smislu problematične se uvrščajo: povedkovnik, členek (zlasti v razmejevanju nasproti prislovu), prvi del zloženk, vrstni pridevnik in področje konverznih tvorjenk nasploh. Problematika tega področja je v nadaljevanju ponazorjena s primeri izbranih leksikalnih enot. Navedbi leksikalne enote $\mathrm{v}$ ponazarjalnem sobesedilu, relevantnem za določanje besednovrstne pripadnosti, 9 sledijo prikazi v Slovarju slovenskega

7 Obstoje tudi druge možnosti modeliranja leksikalnega pomena. Tukaj navedeni, povzet po Slovenskem leksikalnem pomenoslovju, je v slovenističnem slovaropisju pač na prvem mestu med drugim zato, ker je skladen z edinim celovitim pomenskim opisom slovenskega jezika v SSKJ.

${ }^{8}$ Med drugim je to razvidno celo iz vzporednega branja obravnave besednih vrst pri leksikalni bazi v Gantar 2015 in opisom besednovrstne problematike v Černelič 1984. Kljub časovni razdalji so izpostavljena istovrstna vprašanja.

9Za leksikalno enoto, navedeno $\mathrm{v}$ ponazorilu, se predpostavlja, da izpolnjuje pogoje za sprejem v predpostavljeni slovar. 
knjižnega jezika, v prvi izdaji (SSKJ1) in v drugi izdaji (SSKJ2), v Slovarju Slovenskega pravopisa 2001 (SP 2001) in Sinonimnem slovarju slovenskega jezika 2016 (SSSJ), iz katerih je razviden razvoj razmišljanja o besednovrstnosti $\mathrm{v}$ slovenističnem slovaropisju. Iz sprememb, kot so razvidne od slovarja do slovarja, je povzeta ocena, $\mathrm{v}$ kolikšni meri je dana slovarska rešitev v skladu z zahtevo, da je besednovrstna kategorizacija smiselno vgrajena v siceršnji pomenski opis.

\subsection{Povedkovnik}

*Ta kraj je zanj svet.

SSKJ1: svét -a -o prid. ... 5. ekspr., v povedni rabi ki ima za koga zelo veliko vrednost zaradi svoje povezanosti s čim zelo cenjenim, ljubljenim: ta kraj je zanj svet; zakon jim je bil svet in nedotakljiv; izgubil je vse, kar mu je bilo sveto

SP: svét -a -o ... poud. svet komu/čemu Ta stvar mu je a |ima zanj zelo veliko vrednost|; svet za koga/kaj Ta kraj je zanj |ima zanj zelo veliko vrednost|

SSKJ2: $=$ SSKJ1

SSSJ: svét 4 -a -o povdk. 1. |izraža, da je kaj zaradi popolnosti, izjemnosti vredno najvišjega čaščenja, spoštovanja| Vsako življenje je sveto... SINONIMI: božanski, božanstveni 2. komu/za koga ekspr. |izraža, da ima kaj za koga zelo veliko vrednost zaradi povezanosti s čim zelo cenjenim, ljubljenim| Materni jezik je bil Slovencem v nekaterih časih svet SINONIMI: svetinja, sveta stvar, sveto, paladij, relikvija

Na osnovi pomenske analize je v SSKJ1 povedkovniški pomen pri 5. prikazan pri pridevniku v samostojni pomenski enoti, pomenskorazlikovalno opremljeni s slovničnim kvalifikatorskim pojasnilom »v povedni rabi«. Navedena je torej skladenjska značilnost, $\mathrm{s}$ katero se ta pomenska enota razlikuje od prejšnjih (od 1. do 4.). ${ }^{10}$ Pomen ima samostojno razlago, ki pa ne vključuje kategorialne

${ }^{10} \mathrm{~V}$ skladu s sodobnim slovenističnim leksikološkim védenjem je povedkovniški tudi pomen 1. (Bog je svet), medtem ko nadaljnji pomeni vključujejo stalne besedne zveze, v katerih nastopa vrstni pridevnik, torej leksikalna enota sveti -a -o prid. : 1. sveti Duh, sveta družina, (opomba se nadaljuje na naslednji strani) 
prilagoditve in je tipsko enaka razlagi lastnostnega pridevnika v prilastkovni funkciji. Vezljivost kot kategorialna pomenska lastnost (za koga in variantno komu) je prikazana na ravni slovarskega ponazorila, kot besedilna danost, in ne kot strukturna značilnost. Povedkovniški pomen kot leksikalni pomen je bil v SSKJ1 torej na osnovi gradivne analize ustrezno prepoznan in osamosvojen z navedbo skladenjske značilnosti »V povedni rabi«, izrazna raven slovaropisnega prikaza (formulacija razlage, (ne)navedba vezljivostnega določila) pa odraža značaj sočasnega pojmovanja predikativnosti v slovnici, pri katerem se predikativnost ni eksplicitno povezovala $\mathrm{s}$ specifičnostjo leksikalnega pomena.

V SP 2001 je obravnavani pomen prikazan z navedbo leksema v podiztočnici in eksplicitnim izpisom vezljivostnega določila, vendar brez eksplicitne navedbe, da se podiztočnica nanaša na novi, od pridevniške iztočnice besednovrstno različni povedkovniški leksem. Iz prikaza ni prav razvidno, ali podiztočnica ni morda mišljena samo kot izpostavitev besedilne rabe, sicer prikazane $\mathrm{v}$ slovarskem ponazorilu, ki sledi podiztočnici. Mehanično navajanje vezljivostne oznake v obeh variantah, za vezljivostno določilo s kategorialno pomensko sestavino človeško+ in človeško- ( $k o m u / c ̌ e m u, k o g a / k a j)$, nadalje dokazuje, da slovarski prikaz ne temelji na upoštevanju leksikalnega pomena, saj bi upoštevaje pomen morala biti navedena samo vezljivost za človeško+. ${ }^{11}$ Glede na siceršnje navajanje povedkovnikov v tem slovarju ${ }^{12}$ postane neupoštevanje leksikalnega pomena še bolj razvidno, saj vse kaže, da izpridevniški povedkovniki (npr. svét -a -o komu) niso prepoznani kot samostojna

sveta brata Ciril in Metod; 1.// sveti kraji itd.; 3. sveti bik itd; 3.// svete knjige itd.; 6. sveti mir; 6.// sveta dolžnost.

11 Primere iz SP na tem mestu navajamo zgolj zaradi prikaza besednovrstne problematike. Odsotnost leksikografsko domišljenega koncepta pri Slovarju Slovenskega pravopisa sicer onemogoča kritično razmišljanje o leksikografskih rešitvah v tem slovarju, pri obravnavanem primeru npr. navedba dveh ponazoril, ki imata zapostavljeno isto razlago (»ima zanj veliko vrednost «).

12 Prim. sestavke pri blagor (Pravi blagor je, da...), bomba (Film je bil bomba), človeško (Človeško je biti žalosten), čudež (Čudež je bilo, da je ...), hudo (Hudo mi je bilo pri srcu) itd. 
besednovrstna kategorija, kljub enakovrednosti $\mathrm{z}$ izsamostalniškimi povedkovniki (blagor, bomba, čudež) in izprislovnimi povedkovniki (človeško, hudo). Pojmovanje povedkovnika v slovarskem delu Slovenskega pravopisa 2001 tako ostaja na pol poti. Pridevniški leksem dobi vezljivostno

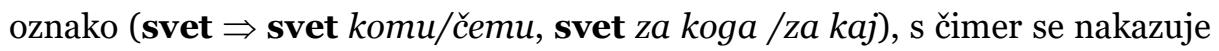
neka strukturna povezava z glagolskimi besednovrstnimi lastnostmi, in nič več kot to. Povedkovniška pomenskost in besednovrstna razlikovalnost ostajata nepojasnjeni, celo manj pojasnjeni kot v SSKJ, kjer je povedkovniškost $\mathrm{v}$ povezavi z leksikalnim pomenom razmeroma sistematično in natančno v vseh primerih izražena s slovničnim kvalifikatorskim pojasnilom »v povedni rabi«. Neusklajenost slovarskih rešitev v slovarju SP (različni prikaz izsamostalniških in izpridevniških povedkovnikov) dodatno vnaša nejasnost glede pojmovanja povedkovnika.

Druga izdaja SSKJ na področju pojmovanja povedkovniške besednovrstnosti dejansko ne prinaša nobenih izpopolnitev v primerjavi s prvo izdajo, in to kljub siceršnjemu navajanju oznake povdk. ${ }^{13}$

V SSSJ je obravnavani povedkovniški pomen (Ta kraj je zanj svet) eden od dveh pomenov, navedenih $\mathrm{v}$ slovarskem sestavku povedkovniške iztočnice svét 4 -a -o povdk., ki je na četrtem mestu med homonimi: svét ${ }^{1}$-á $\mathrm{m}$, svèt ${ }^{2}$ svéta $\mathrm{m}$, svét3 -a oo prid. (SINONIM dober $\mathrm{v}$ pomenu 'ki kaže pozitivne moralne lastnosti') in svét 4 -a -o povdk. ${ }^{14}$ Različna nabora sinonimov med drugim dokazujeta, da ima povedkovnik svét -a -o dva različna povedkovniška pomena. Slovarska razlaga obeh pomenov je oblikovana tako, da odraža kategorialno specifičnost povedkovniškega pomena ('izraža, da ...'). Pri drugem pomenu je v obliki zaimenske izpostavitve navedeno vezljivostno določilo $\mathrm{v}$ obeh ugotovljenih variantah (svet komu, svet za koga), kot je v celotnem

${ }_{13} \mathrm{~V}$ uvodu k drugi izdaji SSKJ je sicer navedeno, da je obravnava povedkovnika usklajena $\mathrm{S}$ SP 2001, vendar slovarski sestavki tega ne potrjujejo.

14 Poleg navedenih homonimnih iztočnic je sicer v SSSJ še iztočnica svéti -a -o prid. (sestavina stalnih besednih zvez) in večbesedna iztočnica vsi svéti vseh svetih $\mathrm{m} \mathrm{mn}$. v pomenu 'praznik'. 
slovarju določeno za prikaz kategorialne pomenske sestavine, uresničujoče vezljivost kot kategorialno pomensko lastnost glagola. Tako je površinsko izkazana tipska povezanost povedkovniškega besednovrstnega pomena $\mathrm{z}$ glagolskim pomenom in na ravni slovaropisnega prikaza upoštevano pomenoslovno dejstvo, da je povedkovnik imenski del zloženega glagola z lastnim leksikalnim pomenom (Snoj 2010: 94-151). V sinonimnem slovarju prikaz sinonimije, sinonimnega razmerja med leksemi že sam po sebi narekuje, da se besednovrstna določitev leksikalne enote upošteva dosledno znotraj leksikalnega pomena kot celovite pomenske danosti. Prikaz sinonimije, kot ga posreduje slovarski sestavek pri svét 4 -a -o povdk. v SSSJ, prepričljivo kaže, da je prav ustrezno upoštevanje in eksplicitno izkazovanje besednovrstne kategorialnosti ( $\mathrm{v}$ tem primeru povedkovniške) tisto, ki v slovarskem priročniku v temelju omogoča pregleden in verodostojen prikaz pomenskih danosti.

\section{2 Členek}

${ }^{*}$ Hoja je gotovo zdrava. ( $\leftarrow$ Hoja je zdrava. $\{\mathrm{O}$ tem sem prepričan. $\left.\}\right){ }^{*} J u t r i$ gotovo pridem. ( $\leftarrow$ Jutri pridem. $\{\mathrm{O}$ tem ni potrebno dvomiti, odločitve ne bom spreminjal.\})

SSKJ1: gotòv -óva -o prid. ... gotóvo 1. prislov od gotov: na ta način se da najbolj gotovo ugotoviti, kako se ptice selijo ... 2. nav. ekspr. izraža a) prepričanost o čem: takemu delu gotovo ne bo kos ... b) v povedni rabi podkrepitev trditve: gotovo je, da o tem ne bi smel govoriti ... c) nepreklicnost česa: gotovo bom naredil do jutri 3 . v medmetni rabi izraža a) nepreklicnost česa: vrnem vam z obrestmi, gotovo ... b) soglasje, pritrditev: »tega ne bi smel reči.« »Gotovo, predaleč je šel « ...

SP: gotôvo soglaš. člen. To bo držalo; Počakaj me, pridem; Vrnem vam z obrestmi,

(gotôvo' ${ }^{1}$ nač. prisl. Glas mu je zvenel )

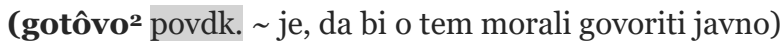


SSKJ2: = SSKJ1, le spremenjeni naglas gotôvvo in sprememba pri gotôvo 2.: v členkovni rabi izraža a) prepričanost o čem: takemu delu gotovo ne bo ... (nadaljevanje enako kot v SSKJ1)

SSSJ:

(gotôvo' ${ }^{1}$-ega s 'gotovina')

(gotôvo² prisl. 'samozavestno, odločno')

gotôvo3 ${ }^{3}$ poudar. člen. 1. |poudarja prepričanost o čem| Hoja je gotovo zdrava SINONIMI: brez dvoma, brez oklevanja, definitivno ... 2. |poudarja nepreklicnost česa| Jutri gotovo pridem SINONIMI: zagotovo, gvišno, vsekakor, za prmej ... GLEJ ŠE pri dominantah: res (1. soglašalni členek: Gotovo, to ni pošteno, 2. poudarjalni členek: Gotovo ne lažem), seveda (soglašalni členek: Me vzameš s sabo? Gotovo)

(gotôvo 4 povdk. |izraža, da je kdo prepričan o resničnosti trditve| O tem bi morali razpravljatijavno; to je gotovo SINONIMI: dejstvo, enkrat ena, fakt, faktum, nesporno, zagotovo)

Iz navedenih slovarskih prikazov členka gotovo je razvidno, kako je besednovrstno določanje vključevalo določeni razvoj, ki prav v zvezi s to besedno vrsto še vedno nima zaključka v povsem jasnih definicijskih merilih (Balažič Bulc 2017). Za slovarski pomenski opis pa so bistvene prav enoumne, zanesljive besednovrstne določevalne lastnosti. Če za členek morda še ni ugotovljen popolni nabor besednovrstno razlikovalnih lastnosti, imajo v slovarskem pomenskem opisu toliko večji pomen tiste, ki so doslej nedvoumno ugotovljene. Pri členku je to njegova temeljna razlikovalnost $\mathrm{v}$ primerjavi s prislovom, razvidna $\mathrm{v}$ dejstvu, da ima prislov vselej določujočo vlogo za glagolski, pridevniški ali prislovni pomen, nikoli pa za samostalniški pomen; prislov odgovarja na vprašalnico, členek ne. Pomenska specifičnost členka, da ima sicer težko določljive kategorialne pomenske lastnosti in da je v mnogih primerih konverzno tvorjen iz prislova, ne opravičuje mešanja s prislovom in povedkovnikom $\mathrm{v}$ primerih, ko je prislovni in povedkovniški pomen nedvoumno prisoten. 
Vzemimo primer: Hudičevo se moti, kdor tako misli (Žele 2015: 29). Po obstoječih slovarskih prikazih (SSKJ1, SSKJ2, SSSJ, SP) je hudičevo v tem primeru v vlogi prislova, saj nedvoumno določa glagol. $\mathrm{V}$ besedilnem gradivu je te vrste izrazitev s prislovom hudičevo na pretek, s tako rekoč vsemi vrstami glagolov in pridevnikov (hudičevo se naprezati/uspevati itd., hudičevo mrzel/lep itd.), tako da je neproblematičnih potrditev za prislov v tem primeru dovolj. V Slovarju slovenskih členkov je hudičevo v tej vlogi opredeljen kot členek, celo z navedeno zamenljivostjo z »zelo « in »prekleto « (Žele 2015: 29). ${ }^{15}$ Iz podobnih primerov v Slovarju slovenskih členkov je razvidno, da se razumevanje in definiranje besedne vrste kot kategorialnopomenske danosti meša $\mathrm{z}$ zaznavanjem konotativnega in pragmatičnega pomena, kot ga uresničuje hudičevo $\mathrm{v}$ navedenem primeru in kar dokazuje zapisana razlaga: »izraža močno čustveno prizadetost«. »Močna čustvena prizadetost« je udeležena v izbiri stilno močno označenega prislova hudičevo (namesto npr. stilno neoznačenega zelo), torej $\mathrm{v}$ izbiri določene izrazitvene variante, ki vključuje visoko stopnjo ekspresivnosti $\mathrm{v}$ konotativnem pomenu. Izbira izrazitve s konotativnim pomenom (ekspresivnost) je eno, kategorialni pomen izbranega leksema pa drugo. $\mathrm{V}$ tem primeru je hudičevo prislov, ki intenzivnostno določa glagolsko dejanje, izraženo z glagolom motiti se.

Podobno je v Slovarju slovenskih členkov kot členek obravnavan leksem hudič v primerih: Hudič je stati dve uri na mrazu ali Hudič je, če te nihče ne uboga in Hudič je vse skupaj (Žele 2015: 29). Vsi trije primeri so uresničitve stanjskega metaforičnega povedkovnika hudíč s pomenom 'izraža stanje, ki ga kdo doživlja kot neprijetno, težavno', za katerega je nevtralna izrazitev s povedkovnikom hudó in sinonimi težko, bog pomagaj, groza, grozno, grozota, pokora, obupno, zafrknjeno itd.

\footnotetext{
15 Niti navedba prislova zelo kot zamenljivostne variante $\mathrm{k}$ hudičevo, kar bi samo po sebi zahtevalo enako besednovrstno določitev glede na osnovna pravila usklajenega slovarskega prikaza, ni avtorice napeljalo k ugotovitvi napake.
} 


\subsection{Izdeležniške tvorjenke}

*Usekani prst ga boli. - *Usekan je na meso. - *Usekan je nanjo.

SSKJ1: usékati -am dov. ... usékan -a -o 1. deležnik od usekati: usekana roka ga boli 2. pog., ekspr. čudaški, neumen: lepa je res, vendar usekana 3. pog., ekspr., navadno v povedni rabi, v zvezi z na ki čuti, ima veliko željo po tem, kar izraža določilo: usekan je na delo, ples; biti usekan na meso / usekana je nanj zelo ga ima rada

SP: usékan -a -o ... Vsak je po svoje čudaški, omejen usekan na koga/kaj biti $\sim$ delo |zelo rad delati|; Čisto $\sim$ a je nanj |zelo ga ima rada|

$\mathrm{SSKJ} 2=\mathrm{SSKJ} 1$

SSSJ: usékan¹ -a -o prid. $\Rightarrow$ neumen (usekan človek)

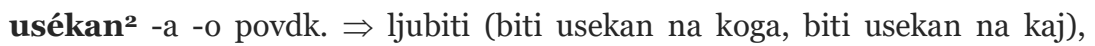
čudaški (biti malo usekan, biti po svoje usekan)

${ }^{*}$ Radje športno oblečen.

SSKJ1: obléči oblečem ....obléčen -a -o: sem že oblečen in obut

SP: obléči oblečem dov. obléci -te/-íte; oblekel -kla, obléč/oblèč, obléčen -a; obléčenje ...

$\mathrm{SSKJ} 2=\mathrm{SSKJ} 1$

SSSJ: obléčen -a -o povdk. $\Rightarrow$ nositi (nositi civilno obleko = biti oblečen $v$ civil ...), oblačiti se (športno se oblačiti = biti športno oblečen)

Izdeležniške tvorjenke $\mathrm{v}$ doslejšnjih slovarskih prikazih narekujejo jasno ločevanje med (1) deležniškim pomenom, (2) povedkovnikom, (3) izdeležniškim lastnostnim pridevnikom in (4) izdeležniškim vrstnim pridevnikom. Razlikovanje je razvidno že v SSKJ1, npr. v zgoraj navedenem sestavku pri usekati, kjer je deležnik prikazan v podiztočničnem lastnem sestavku. Deležniški pomen je pri 1. eksplicitno izkazan z razlago »deležnik od«. Pri tem pomenu je v primerjavi z izhodiščnim glagolom prisotna samo 
kategorialnopomenska sprememba: dejanje $\Rightarrow$ posledica dejanja, ne da bi prišlo do spremembe $\mathrm{v}$ denotativnem pomenu. $\mathrm{V}$ levem prilastku je pri tem pomenu zmeraj prisotna določnost: * usekati prst $\Rightarrow{ }^{*}$ Prst je usekan $\Rightarrow$ *Usekani prst ga boli. Pri 2. je prikazan lastnostni pomen, in sicer s sinonimno razlago (čudaški, neumen), ki $\mathrm{v}$ slovarju najbolj prepričljivo potrjuje razmeroma težko ulovljivi in redko resnično lastnostni pomen izdeležniškega pridevnika. Pri 3. je prikazan povedkovniški pomen, vezljivost je delno celo izpostavljena (»v zvezi $\mathrm{z}$ na«). SP tudi $\mathrm{v}$ tem primeru ostaja na pol poti. Iztočnica usékan -a -o je pridevniška, čeprav so vsa ponazorila povedkovniška. Vezljivost je izpostavljena, iz zapostavljene razlage je razvidno, da gre za povedkovniški pomen, in ne za pridevniški. SSKJ2 ne prinaša spremembe $\mathrm{v}$ primerjavi s SSKJ1. SSSJ ločuje pridevniško iztočnico, s katero izdeležniški lastnostni pridevnik usekan pošilja $\mathrm{v}$ sinonimni niz pri neumen, in povedkovniško iztočnico, iz katere je razvidno, da je usekan kot povedkovnik udeležen v izrazitvah, sinonimnih z ljubiti in biti čudaški.

Za primer izdeležniškega vrstnega pridevnika (4. kategorija izdeležniških tvorjenk) se lahko navede obložêni -a -o prid., kot je udeležen v večbesedni leksikalni enoti obložena govedina.

\section{NEKATERE SMERNICE ZA BESEDNOVRSTNO KATEGORIZIRANJE V PRIHODNJIH SLOVENSKIH SLOVARJIH}

5.1 Besednovrstna kategorialnost je v slovaropisju videna znotraj leksikalnega pomena kot celote, in sicer natanko v okviru kategorialnega pomena. Pri besednovrstnem kategoriziranju v slovarju je potrebno dosledno upoštevati, da poimenovalni sistem (slovar) in slovnica nista ločeni jezikovnosistemski danosti, pač pa različni področji enega kontinuuma. Model leksikalnega pomena, v katerem se pomen modelira kot hkratnost denotativnega, kategorialnega, konotativnega in pragmatičnega pomena, je pri utemeljevanju besednovrstne kategorizacije uporaben, ker lahko pripomore $\mathrm{k}$ doslednemu uvrščanju besednovrstne kategorizacije na določeno »mesto« v celovitem 
pomenskem opisu.

5.2 Besednovrstna kategorizacija kot področje specifične slovaropisne problematike je enovito obvladljiva, če se rešuje v okviru jasne predstave, kaj je leksikalna enota in kaj leksikalni pomen, iz slovnice vzeti pojem besedna vrsta in tamkajšnja definicija različnih besednih vrst pa je ob tem pragmatično uporabljeno orodje za identifikacijo istovrstnih pomenskih danosti. Za slovarski pomenski opis je besedna vrsta kategorija, obstoječa kot nabor kategorialnih pomenskih lastnosti. ${ }^{16}$ Besednih vrst je toliko, kolikor je ugotovljenih različnih naborov kategorialnih pomenskih lastnosti, s katerimi se $\mathrm{v}$ danem jeziku medsebojno razlikujejo skladenjske vloge in hkrati s temi tipski denotativni pomen (npr. samostalniška besedna vrsta za poimenovanje stvari, oseb, pojmov; glagol za poimenovanje dogodkov itd.). ${ }^{17} \mathrm{~V}$ tukajšnjem prispevku je izpostavljen strukturalni model slovarskega pomena, ker je edini preizkušeni $\mathrm{v}$ doslejšnjem slovenističnem slovarstvu, čeprav ga lahko nadomesti kateri drugi. Pomembno je, da je slovaropiscu jasno, kaj mu znotraj izbranega pojmovanja, kaj je leksikalni pomen, pomeni besedna vrsta.

5.3 Določanje leksikalnih enot $\mathrm{z}$ besednovrstnimi oznakami v slovarskem priročniku je v vsakem primeru uvrščanje dane leksikalne enote v določeno besednovrstno kategorijo, tj. povezovanje, identificiranje določene leksikalne enote $\mathrm{z}$ besedno vrsto kot abstraktno danostjo, in to $\mathrm{v}$ vseh primerih, ne glede

16 Kako v tem okviru vzpostaviti ustrezno povezavo med leksikalno bazo in slovarskim priročnikom, $\mathrm{v}$ katerem se pričakuje eksplicitna pomensko utemeljena besednovrstna kategorizacija, je posebno vprašanje. Vsekakor je uporabnost leksikalne baze omejena, če v njej niso realno izkazane kategorialne pomenske lastnosti leksikalnih enot (če npr. lastnostni pridevniki niso jasno razlikovani od vrstnih pridevnikov, če metaforični konverzni izsamostalniški povedkovnik ni ločen od izhodiščnega samostalnika ali pa če je posamostaljenje evidentirano z brezobrazilno pridevniško obliko).

$17 \mathrm{~V}$ tem okviru je potrebno razumeti tudi razvojnost slovenističnega nauka o besednih vrstah. V SSKJ ni členka, ker ob začetku tega dela, prvega razlagalnega slovarja slovenskega jezika, še niso mogle biti identificirane tipske pomenske značilnosti, $\mathrm{s}$ katerimi se členek razlikuje od prislova. Prav tako v SSKJ ni oznake povedkovnik, pač pa pogosto slovnično kvalifikatorsko pojasnilo »v povedni rabi «, ki z imenovanjem zgolj skladenjskega mesta nakazuje, da gre za posebni pomen dane leksikalne enote, ne da bi bili že ugotovljeni tipski pomeni povedkovnika kot besedne vrste (lastnostnodoločitveni pomen, stanjski pomen itd.). V Slovarju SP 2001 povedkovnik že nastopa kot posebna besednovrstna kategorija na osnovi skladenjske vloge, medtem ko tipski leksikalni pomen povedkovnika kot besedne vrste ni določen. 
na to, ali se določitev nanaša na prvotno besednovrstno kategorialnost ali na konverzno pridobljeno. Zato razlikovanje med eksplicitno navedbo besednovrstne oznake pri dani leksikalni enoti (npr. navedbo rodilniške končnice in oznake za spol pri samostalniških leksikalnih enotah) in posrednim določanjem besednovrstnosti (npr. »kot samostalnik«, »kot pridevnik «ipd.) s stališča sinhronega pomenskega opisa ni smiselno. Prav tako je s stališča slovaropisja zanemarljivo, ali se določena kategorija interpretira kot »skladenjsko-pomenska kategorija « (Žele 2003) ali kot »besedna vrsta«. V slovarskem priročniku je pomembno, da je slovarniku jasno, katero kategorialnopomensko vsebino simbolizirajo uporabljene besednovrstne oznake.

5.4 Konverzne tvorjenke so samostojne leksikalne enote $\mathrm{z}$ lastno leksikalnopomensko vrednostjo, kar mora biti v slovarskem pomenskem opisu podprto z jasno besednovrstno določitvijo. Izkazovanje povezanosti, ki obstoji med leksikalnimi enotami zaradi konverzne tvorjenosti (sistem podiztočnic ipd.), je drugotno $\mathrm{v}$ primerjavi $\mathrm{s}$ tem, da morajo biti konverzne tvorjenke $\mathrm{v}$ slovarju pomensko opisane kot samostojne leksikalne enote.

5.5 Razločna prisotnost besednovrstnega označevanja in dosledno upoštevanje meril pri dodeljevanju besednovrstnih oznak v celotnem slovarju, od začetka do konca, zanesljivo veliko prispeva k uporabnosti slovarskega priročnika.

\section{ZAKLJUČEK}

Pojmovanje besednovrstne kategorizacije $\mathrm{v}$ slovarskem pomenskem opisu se podreja dejstvu, da je slovar kot jezikovni priročnik namenjen prikazu pomenskosti. Slovar je pri besednovrstnem kategoriziranju dolžen upoštevati spoznanja in definicijske zmožnosti slovnične znanosti, za slovenski jezik razmeroma obsežne in temeljite, in sicer v smislu čim bolj jasnega ločevanja med različnimi besednimi vrstami. Hkrati pa mora biti slovaropisje kritično do priložnostnega slovničarskega eksperimentiranja in $\mathrm{v}$ jezikoslovni teoriji nujnega teoretičnega relativiziranja definicijskih lastnosti posameznih 
besednih vrst. Obstoječe védenje o besednih vrstah v slovenskem jeziku se bo v slovničarskem preučevanju $\mathrm{v}$ prihodnje še širilo $\mathrm{z}$ novimi pogledi in ugotovitvami. V slovaropisju pa je pomembno, da so merila za besednovrstno določanje leksikalnih enot razlikovalno utemeljena in v slovarski zasnovi jasno določena. Relativiziranje in mešanje meril, prisotno v drugi izdaji SSKJ (Ahlin 2014) in v Slovarju slovenskih členkov, v slovaropisju ni perspektivno.

V postopku praktične izdelave določenega slovarja o obliki in načinu izraženosti besednovrstne kategorizacije odloča zasnova slovarja, in sicer v okviru svoje temeljne vloge, da natančno predvidi vsebino in zgradbo načrtovanega slovarja in v sami sebi zagotovi konsistentnost posameznih slovarskih rešitev v njihovi medsebojni povezanosti. $\mathrm{V}$ zvezi z besednovrstno kategorizacijo je pri tem odločilna jezikoslovna izobraženost načrtovalca slovarja in njegova ambicioznost glede stopnje natančnosti v prikazu leksikalnopomenskih razlik med leksikalnimi enotami. Ob dovolj znižani natančnostni ravni v izkazovanju leksikalnopomenskih danosti se še dalje lahko ignorira doslejšnje ugotovitve v zvezi s pomensko razločevalnostjo v slovenskem jeziku: lahko se meša prislove in členke, lahko se ukine povedkovnik in pri roki je povratek $\mathrm{v}$ preživeto preteklost s pojmom »nesklonljivo«; v imenu »rabe« se lahko zanemari obrazilno izraženo pomensko razlikovalnost med vrstnimi pridevniki ter lastnostnimi pridevniki ipd. O tem, kako bodo že doslej prepoznane pomenskorazlikovalne danosti, med katerimi so besednovrstne kategorije temeljne, izkazane v prihodnjih slovarjih, odločata zgolj zmožnost in hotenje slovarnikov, koliko natančen in glede na jezikovno realnost verodostojen pomenski opis so sposobni udejanjiti.

\section{LITERATURA}

Ahlin, M., B. Lazar, Z. Praznik, in J. Snoj (2014): Slovar slovenskega knjižnega jezika. Druga, dopolnjena in deloma prenovljena izdaja. Jezik in slovstvo 59/4. 121-127.

Attkins, B. T. S., in M. Rundell (2008): The Oxford Guide to Practical 
Lexicography. Oxford: Oxford University Press.

Balažic Bulc, T. (2015): Členek v slovenskem jezikoslovju in slovarju. V V. Gorjanc idr.: Slovar sodobne slovenščine: problemi in rešitve. 524538. Ljubljana: Znanstvena založba Filozofske fakultete UL.

Černelič-Kozlevčar, I. (1988): Reševanje besednovrstnih vprašanj v Slovarju slovenskega knjižnega jezika. Obdobja 8, 289-300. Ljubljana: Filozofska fakulteta.

Gantar, P. (2015): Leksikografski opis slovenščine v digitalnem okolju. Ljubljana: Znanstvena založba Filozofske fakultete UL.

Grošelj, R. (2015): Besedne vrste v slovenskem jeziku. V V. Gorjanc idr.: Slovar sodobne slovenščine: problemi in rešitve. 498-513. Ljubljana: Znanstvena založba Filozofske fakultete UL.

Landau, S. I. (1989): Dictionaries. The Art and Craft of Lexocography. Druga izdaja. Cambridge: Cambridge University Press.

SSKJ: Slovar slovenskega knjižnega jezika (1970-1991/spletna različica: 2000). Ljubljana: ZRC SAZU. Dostopno prek: https://fran.si/.

SSKJ2: Slovar slovenskega knjižnega jezika (2014). Druga, dopolnjena in deloma prenovljena izdaja. Dostopno prek: https://fran.si/.

SP: Slovenski pravopis (2001). Ljubljana: ZRC SAZU. Dostopno prek: https://fran.si/.

Snoj, J. (2010): Metafora v leksikalnem sistemu. Ljubljana: Založba ZRC, ZRC SAZU.

Snoj, J. (2015): Od definicije besedne vrste v slovnici do besednovrstne oznake v slovarju. Slovenski jezik 10. 163-175.

Stramljič Breznik, I. (2014): Medmeti v slovenskem jeziku. Maribor: Založba Pivec. 
Toporišič, J. (2004): Slovenska slovnica. Maribor: Založba Obzorja.

Vidovič Muha, A. (2013): Slovensko leksikalno pomenoslovje. Druga, dopolnjena izdaja. Ljubljana: Znanstvena založba Filozofske fakultete.

Žele, A. (2003): Slovarska obravnava povedkovnika. Jezik in slovstvo 48/2. $3-15$.

Žele, A. (2015): Slovar slovenskih členkov. Ljubljana: Založba ZRC, ZRC SAZU. 


\section{WORD-CLASS CATEGORIZATION AS A \\ GRAMMATICAL FOUNDATION OF THE LEXICOGRAPHIC DESCRIPTION OF MEANING}

The paper deals with word-class categorization from the standpoint of providing word-class tags in dictionaries of Slovene at a general level, applicable regardless of the lexicographic concept. We first demonstrate the individuality of word-class categorization in the theory of grammar, followed by the demonstration of the role of word-class categorization of lexical units within the description of meaning in a dictionary. Providing examples for the predicative, particle, and participial compounds, we demonstrate the development of word-class categorization in the existing Slovene dictionaries and provide guidelines for future dictionaries of Slovene.

Keywords: linguistic description, meaning, grammar

To delo je ponujeno pod licenco Creative Commons: Priznanje avtorstvaDeljenje pod enakimi pogoji 4.o Mednarodna.

This work is licensed under the Creative Commons Attribution-ShareAlike 4.0 International.

https://creativecommons.org/licenses/by-sa/4.0/

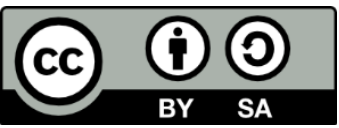

